\title{
Article
}

\section{Discovering golf's innermost truths: A new approach to teaching the game: $\mathbf{A}$ Commentary}

Grecic, D., and Collins, D.

Available at http://clok.uclan.ac.uk/12418/

Grecic, D., ORCID: 0000-0003-1487-8327 and Collins, D. ORCID: 0000-00027601-0454 (2010) Discovering golf's innermost truths: A new approach to teaching the game: A Commentary. International Journal of Sports Science \& Coaching, 5 (S2). pp. 133-137. ISSN 1747-9541

It is advisable to refer to the publisher's version if you intend to cite from the work. http://dx.doi.org/10.1260/1747-9541.5.s2.133

For more information about UCLan's research in this area go to http://www.uclan.ac.uk/researchgroups/ and search for <name of research Group>.

For information about Research generally at UCLan please go to http://www.uclan.ac.uk/research/

All outputs in CLoK are protected by Intellectual Property Rights law, including Copyright law. Copyright, IPR and Moral Rights for the works on this site are retained by the individual authors and/or other copyright owners. Terms and conditions for use of this material are defined in the policies page.

\section{CLoK}

Central Lancashire online Knowledge www.clok.uclan.ac.uk

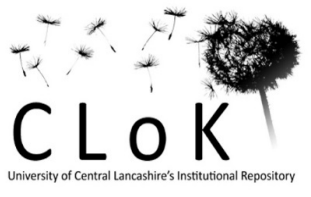




\title{
Discovering Golf's Innermost Truths: A New Approach to Teaching the Game
}

\author{
A Commentary \\ David Grecic and Dave Collins \\ International Institute for Golf Education \\ University of Central Lancashire \\ Preston, Lancashire, PR1 2HE, UK \\ E-mail: dgrecic1@uclan.ac.uk; dave@gm4p.com
}

\section{INTRODUCTION}

It is always good to see additions to the sport literature focused on the crucial constructs of skill acquisition and motor control. Given that performance is largely dependent on effective learning then efficient execution of skills, understanding and enhancing the mechanisms through which this is accomplished are woefully neglected [1].

As a starting point, it is generally agreed that the ability for high-level sports performers to achieve a psychological state appropriate for executing their well learned skills is vital. Therefore, a golfer's ability to regulate arousal levels, expectations, confidence, and attention focus is crucial if they are to perform at their maximum levels. In golf at the elite level, peak performance is associated with golfers having a narrow focus of attention, immersion in the present, feelings of confidence, and effective control [2]. For the novice golfer, this same ability to focus clearly on the task at hand, while removing the inevitable self-doubt and nerves, could be invaluable in speeding up the learning process. As such, many of the building blocks that Peter Lightbown offers in his target article may be of real use to the wider golf coaching profession.

\section{REFLECTING AND SUMMARISING CURRENT THINKING}

There are many positive and practical hints in Lightbown's article. Focusing on the author's coaching inputs, one can relate his findings to positive outcomes and practice already evident within the golf coaching industry. The importance of a relaxed and balanced golf swing, for example, is an accepted truth among golf coaches and, as such, yoga is already included in many golf development programmes. The input of Krishnamurti's influence promoting self awareness and the ability to work things out for ourselves is also prevalent in more progressive golf coaching [3]. In such approaches, implicit and autonomous learning techniques are used, with the coach supporting the player in the process of their 'learning to learn'. 
This also links closely to Lightbown's inclusion of Sensory Awareness [4], where one focuses on experiences rather than on remembering and implementing instructions. Once again, existing good practice in golf includes those coaches who embrace 'Teaching Games for Understanding' [5] and 'Play Practice' [6] theories, developing a more instinctive and natural form of playing and coaching the game. Erich Fromm's contribution of the 'having and being mode' is also often embedded in golf coaches who concentrate on the player's motivational focus. These coaches attempt to direct players' attention away from external sources such as the search for the perfect swing and onto more internal processes. Indeed the author's inclusion of Zen techniques as contributing to his coaching theory builds on this element and has also already been widely adopted by golf. Coaches use many Zen-like techniques in order that their players reach the optimum 'flow' state [7], allowing them to 'get into the zone' [8] and achieve their ultimate performance.

The influence of the Alexander Technique can also be seen in much of the postural focus in golf coaching which is used as a means to create optimal performance rather than as a dogmatic instructional model. Examples here include the Peak Performance Golf coaching model [9] and the Graves Golf Academy [10] who have developed postural cues to reduce neck and back tension and facilitate a pain free swing. The inclusion of Tai Chi in the author's model is also interesting. Various golf coaching programmes already utilise this method by promoting the learning of a slowed-down, sequential swing. Indeed the Vision 54 teaching programme actually promotes a Tai Chi swing, as they combine technical golfing proficiency with the social, emotional and spiritual aspects of the game [11]. From a more empirical perspective, sports science research also supports the use of coping strategies related to breathing control, relaxation, and regulation of arousal. Linked to this, the teaching of preperformance routines could be seen in a Tai Chi context parallel to using the learning of a pre-determined sequence of movements to centre one's focus and deal with possible distractions [12].

Finally, Lightbown's inclusion of the Feldenkrais Method which promotes the interconnected nature of movement is also evident in coaches who teach the whole swing rather than breaking it down into a series of intermediary positions which must be attained.

In summary, much of this paper's content reflects current thinking and, as such, it offers a useful and effective synopsis of good ideas.

\section{A DEARTH OF MECHANISTIC AND 'JOINED UP' THINKING}

There is a lack of mechanistic "how it works/fits together" perspective or logical backdrop for the systematic training of coaches. Firstly, we have hopefully developed from an overly simplistic "West vs. East" approach to comparing philosophies. There is a burgeoning literature on movement control under stress $[1,13]$ and methods of skill acquisition and modification $[14,15]$ which offer an almost perfect match to traditional Eastern concepts such as 'mushin-no mushin' (mind-no mind). Crucially, however, the more recent and scientific approaches offer mechanisms through which these concepts can be understood and transferred more easily to meet novel situations and individual foibles.

Secondly, consider the extent to which the plethora of approaches described by 
Lightbown are actually identical; do they offer consistent advice on how one should coach in any given situation? We suggest not; there are sometimes subtle, but practically crucial differences, between these methods when they are applied. At the very least, they emanate from different philosophical conditions. In a complex and dynamic situation such as optimising skill acquisition, what methods are selected, when and why is increasingly acknowledged as the basis for good coaching [16].

\section{DEVELOPING COACH DECISION MAKING}

As highlighted above there are inherent dangers in constructing a new coaching theory using an amalgam of philosophical drivers and scientific mechanisms. A possible alternative way of developing and assessing such a theory is to concentrate on the coach's Decision Making Chain. This chain is the process by which the overall beliefs and values embedded in the coach's philosophy are transferred and evident in every element of the coaching methods, practices, behaviours and interactions employed.

If such a coherent Decision Making Chain were evident in Lightbrown's 'New Approach to Teaching the Game; we would expect to see its tenets explicit in every stage of the coaching interaction. With such a large number of contributants to his overall philosophy, however, this is obviously difficult to achieve. Taking one element to illustrate this point, that of Zen Buddhism, there are a number of things that we would be looking for to corroborate its effective use in a coherent Decision Making Chain. At the highest level, the coach's ultimate aim would be to create an independent golfer who could perform under the most testing conditions by entering a state of 'no-mind-ness' and 'emptiness' [17]. This would reflect Zen's focus on seeking enlightenment and the removal of the distracting factors of one's self [18]. The coach / player relationship fostered would therefore be one of teacher and pupil, with the coach fostering a conducive learning environment. The coaching methods would strive to generate 'effortless effort' [8]. The coach would avoid the focus on technical knowledge and execution. Practices would attempt to remove any conscious effort from the golf swing. Concentration exercises to reduce the mind's interference and other sports psychology techniques such as self-talk and hypnosis could also be employed. The competition preparation would target strategies which calmed the player and fostered a state of 'relaxed concentration' [19]. Judgements of progress and success would be based upon how effortless or unconscious the act of hitting the ball had become to the player rather than the technical proficiency of the golf swing. If all these phases are being consciously nurtured and monitored by the coach then we would use this as a basis to judge positively the decision making process.

\section{CONCLUSION}

Although we can see merit in Peter Lightbrown's article, we would suggest that a more focused approach be adopted by golf coaches rather than one which relies on a range of potentially conflicting philosophies. We suggest an alternative in which the coach's core beliefs and values are reflected and explicitly observable in every phase of their Decision Making Chain. 


\section{REFERENCES}

1. MacPherson, A., Collins, D. and Obhi, S., The Importance of Temporal Structure and Rhythm for the Optimum Performance of Motor Skills: A New Focus for Practitioners of Sport Psychology, Journal of Applied Sport Psychology,21(S1), S48-S61, 2009.

2. Cohn, P.J., An Exploratory Study of Peak Performance in Golf, The Sport Psychologist, 5, 1-14, 1991.

3. Mattsson, P., Hassman, P., McCullick, B.A.,and Schempp, P., Swedish Golf Success: Its History and Future, Annual Review of Golf Coaching, 2007, 87-99.

4. Brooks, C.V.W., Sensory Awareness: The Rediscovery of Experiencing, Ross-Erikson, Santa Barbara, CA, 1982.

5. Griffin, L.L. and Butler, J.I., eds., Teaching Games for Understanding: Theory, Research, and Practice, Human Kinetics, Leeds, 2005.

6. Lauder, A., Play Practice: The Games Approach to Teaching and Coaching Sport, Human Kinetics, Leeds, UK, 2001.

7. Csikzentmihalyi, M., Flow: The Psychology of Optimal Experience, Harper and Row, New York, 1990.

8. Gallwey,W.T., The Inner Game of Golf, Jonathan Cape, London, UK, 1979.

9. Peak Performance Golf, http://www.peakperformancegolfswing.com

10. Graves Golf Academy, http://www.swinglikemoe.com

11. Vision 54, http://www.vision54.com

12. Cotterill, S., Collins, D. and Sanders, R., Developing Effective Pre-Performance Routines in Golf: Why Don't We Ask the Golfer? Journal of Applied Sport Psychology, In Press.

13. Beilock, S. L. and Gray, R., Why do Athletes "Choke" Under Pressure?, in: Tenenbaum, G. and Eklund, R.C., eds., Handbook of Sport Psychology, $3^{\text {rd }}$ edn., John Wiley \& Sons, Hoboken, NJ, $2007,425-444$.

14. Beilock, S. L. and Gonso, S., Putting in the Mind vs. Putting on the Green: Expertise, Performance Time, and the Linking of Imagery and Action, The Quarterly Journal of Experimental Psychology: Human Experimental Psychology, 2008, 61, 920-932.

15. Nash, C. and Collins, D., Tacit Knowledge in Expert Coaching: Science or Art?, Quest, 58, 464476. 2006

16. Abraham, A.K. and Collins, D., Effective Skill Development: How Should Athletes' Skills be Developed?, in: Collins, D., Button, A. and Richards, H., eds., Performance Psychology: A Guide for Practitioners, Elsevier, Oxford, In Press.

17. Conze, E., Buddhism: Its Essence and Development, $3^{\text {rd }}$ edn., Bruno Cassirer, Oxford, 1957.

18. Suzuki,D.T., Zen and Japanese Culture, Charles E.Tuttle Co, Inc., Rutland, Vermont, 1959.

19. Orlick, T., In Pursuit of Excellence: How to Win in Sport and Life Through Mental Training, $2^{\text {nd }}$ edn., Leisure Press, Human Kinetics, 1990.

\section{EDITOR'S NOTE}

David Grecic is Director of the International Institute for Golf Education (IIGE) at the University of Central Lancashire (UCLan). A qualified PE teacher and coach himself, David has worked with a wide range of national governing bodies and coaches to establish a number of sports academies in golf, football, rugby union and cricket. David still delivers on coach education and sport development courses at UCLan while furthering his own research in the field of elite sports coaching.

Dave Collins is Director of the Institute of Coaching and Performance (ICaP) at 
the University of Central Lancashire (UCLan). A chartered psychologist with broad experience of support work with elite performers, he was formerly Performance Director at UK Athletics. An experienced coach and coach educator, Dave is involved with Level 4 and professional doctoral training for coaches, and also runs a successful consultancy (www.gm4p.com) in performance across a variety of domains. 